\title{
Influence of multiprofessional work on the production of care and access to primary health care
}

(1) Universidade Federal de Santa Catarina, Florianópolis, Santa Catarina, Brasil.

(2) Universidade de Brasilia, Brasília, Distrito Federal, Brasil.

Research support source: Brazilian Federal Agency for Support and Evaluation of Graduate Education of Brazil - CAPES. Federal District Research Support Foundation - FAP/DF.

Conflict of interests: Nonexistent

\section{(c) (i)}

Received on: December 19, 2017 Accepted on: April 24, 2018

Mailing address:

Magda Duarte dos Anjos Scherer Universidade de Brasília, SCLN 406, Bloco A, $2^{\circ}$ andar, Asa Norte

CEP: 70847-510 - Brasília, Distrito Federal, Brasil

Email:magscherer@hotmail.com
Erica Lima Costa de Menezes ${ }^{(1)}$ Magda Duarte dos Anjos Scherer ${ }^{(2)}$ Flávia Regina Souza Ramos ${ }^{(1)}$

\section{ABSTRACT}

Objective: to analyze how the work of four family health teams, in Brazilian Midwest and South regions, influences the capacity of the services in guaranteeing access.

Methods: this is a descriptive study with a qualitative approach.

Results: the results were systematized in nine elements, namely: (I) formation/ Knowledge of standards; (II) experience; (III) affinity of professionals with a particular theme, grievance or group of people; (IV) professional satisfaction; (V) workload; (VI) management and organization of the work process (VII) teamwork; (VIII) actions carried out with the participation of the community and; (IX) respect for the autonomy of people and different knowledge and cultures.

Conclusion: the identified elements related to the individual issues, the organization of the service and the relationship and participation of the community in the actions of the health unit should be considered both in the training of new health workers and in the formulation of public policies.

Keywords: Health Services Accessibility; Primary Health Care; Family Health Strategy; Health Services 


\section{INTRODUCTION}

The Family Health Strategy (FHS) has been the main strategy used to increase access to actions and services in Primary Health Care (PHC) since the creation of the Brazilian National Health System (SUS). The PHC proposal as a gateway and organizer of the system is a major challenge in the country, both when considering the size and diversity of the scenario, as well as when access is evaluated not only as a population coverage, but as the ability to resolutely respond to individual and collective needs. This means conceiving access as a right linked to citizenship in «an ethical and equitable social model guided by social inclusion and human solidarity ${ }^{1}(p .816)$. To guarantee access, it is necessary to increase the autonomy, which implies listening and respect to the knowledge and cultures of all people involved in the production of care ${ }^{2}$.

The multiprofessional work in the PHC, through the family health teams and the Expanded Team for Family Health (NASF, Portuguese acronym), is organized geared towards increasing the bond, coordination and comprehensiveness of care, equity, accountability and popular participation. The professionals of the teams use diverse technologies, actions, knowledge, norms and values to carry out the work, making choices in the moment of meeting with the users ${ }^{3}$. Those choices are individual and collective, arising from the complexity of health work and the need for a collaborative action in the face of the diversity of possible demands and responses ${ }^{4}$. From this debate of values and norms, present in all work, as well as of the variable degree of exchange between the professions, results in health practices more or less fragmented and committed to the production of qualified care.

Different elements of PHC work are described in the literature in their relation or impact on the guarantee of access to health services, such as: the training of workers ${ }^{5}$; the organization of the work process ${ }^{6}$ and the workload ${ }^{7}$. Also, the norms that guide health practices in daily services, such as working hours and teamwork, depending on how they are used may or may not contribute to increased access. From these evidences, it is a presupposition of this study that in addition to the political, economic, social and ethical issues experienced by society, access is also influenced by elements present in the micropolitics of health work.

Considering that, under the ergological perspective ${ }^{8}$ such as epistemological and ethical position, the questions posed by the present work and the concepts and experiences must be considered from a dialogical relation ${ }^{9}$, the purpose of this article is to analyze how the work of family health teams influences the capacity of primary health care services to guarantee access to care.

\section{METHODS}

The research project was approved by the Research Ethics Committee of the Faculty of Health Sciences of the University of Brasília, case number 491.461 / 2013, following the norms of Resolution $n=466 / 12$.

This is a descriptive study with a qualitative approach, «Family Health Strategy - Technological innovation to increase access, quality and promotion of oral health in Primary Health Care, multicenter study».

Having worked in the PHC as the focus of the research, the scenario was delimited to four health units of the Midwest and South regions of Brazil and the elected participants were the professionals who work in four teams of the Family Health Strategy. The inclusion of the sites and participants was done by intentional sampling based on the following criteria: a) Family health units with full teams including dental health team, independent of their modality; b) Family health teams considered to be of good quality by the municipal and/or district managers, using as a reference the National Policy of Basic Attention and National Policy of Oral Health; c) Preferentially, teams that have a Dental Specialty Center and Family Health Support Unit as reference; d) Teams that have joined the Program for Improvement of Access and Quality, (PMAQ, Portuguese acronym).

The participants' profile is described in Table 1. 
Table 1. Profile of participants

\begin{tabular}{lc}
\hline Variables & N (34) \\
\hline Gender & 24 \\
Feminine & 10 \\
Masculine & \\
\hline Age & 2 \\
25 to 29 years old & 6 \\
30 to 34 years old & 10 \\
35 to 39 years old & 6 \\
40 to 44 years old & 5 \\
45 to 49 years old & 4 \\
50 to 54 years old & 1 \\
$65+$ years old & \\
\hline Occupation & 12 \\
ACS & 6 \\
Nurse's assistant & 4 \\
TSB/ASB & 4 \\
Dentist & 4 \\
Nurse & 4 \\
Doctor &
\end{tabular}

\begin{tabular}{lc}
\hline Education & 7 \\
High School & 11 \\
Vocational training & 9 \\
University degree in area related to health & 2 \\
University degree in other areas & 5 \\
Post-graduate degree in collective health &
\end{tabular}

\begin{tabular}{lc}
\hline Time at APS & \\
Less than a year & 1 \\
1 to 5 years & 10 \\
6 to 10 years & 11 \\
More than 10 years & 11 \\
Undisclosed & 1 \\
\hline
\end{tabular}

\section{Participants by region}

Midwest

South 15

${ }^{*}$ Community health agente (ACS); Oral health technician (TSB); Oral Health Auxiliary (ASB); Primary Health Care (APS)

The fieldwork was preceded by: a) the authorization of the Health Secretariats; b) awareness of the teams to participate; c) the training of researchers; d) the testing of data collection instruments.

The data collection was developed between January and December 2014. The analyzed material included 34 interviews and records of 16 hours of observation (4 work shifts) through scripts intended to know about the actions taken and how the teams were organized to increase access.

Participants were identified according to the professional category with the following codes: community health agent: ACS; dentist: CD; Nurse: E; physician: $\mathrm{M}$; nursing technician: TE; oral health technician: TSB; with region midwest: $\mathrm{CO}$ and South: $\mathrm{S}$ and with the corresponding numbering. The observations were numbered sequentially and identified with the letters NO (Observation Note).

After fluctuating reading, the findings were systematized with qualitative data analysis software, ATLAS TI (Qualitative Research and Solutions), organized into nine elements distributed in three dimensions (Figure 1). The purpose of the analysis was to understand what elements present in the work of the health teams influence the service's ability to ensure access.

\section{RESULTS}

The personal dimension of care and access: from training to job satisfaction

In this first dimension there are four categories that integrate the elements that are more directly linked to the worker itself, representing a deeper personal dimension of the influences that affect the way of producing care and access. It emphasizes the relationship between education and work, not only for the content referred to the formal professional formation, but to the continuous process of building experience and identity throughout the work process, in interaction with knowledge, actions and professional subjects and users.

Most of the workers interviewed (23 out of 34) have more than 6 years of experience in Primary Health Care, however, most of them reported never having read the National Basic Care Policy (PNAB, Portuguese acronym) and/or the National Oral Health Policy (PNSB, Portuguese acronym). Those who claimed to have read them have done so: in college, for the performance of a civil servant selection test, out of curiosity or necessity demanded by the daily work.

I think we should have some time to read. I'm not going to take work home because at home I have other things, just as I do not bring house work here (TECO4).

The regulations related to federal programs contribute to both the expansion of actions and the overloading of workers.

Health in the School Program is a channel to promote educational activities. We hade visual acuity tests and, related to dentistry, there was dental brushing [...] (TECO3). 


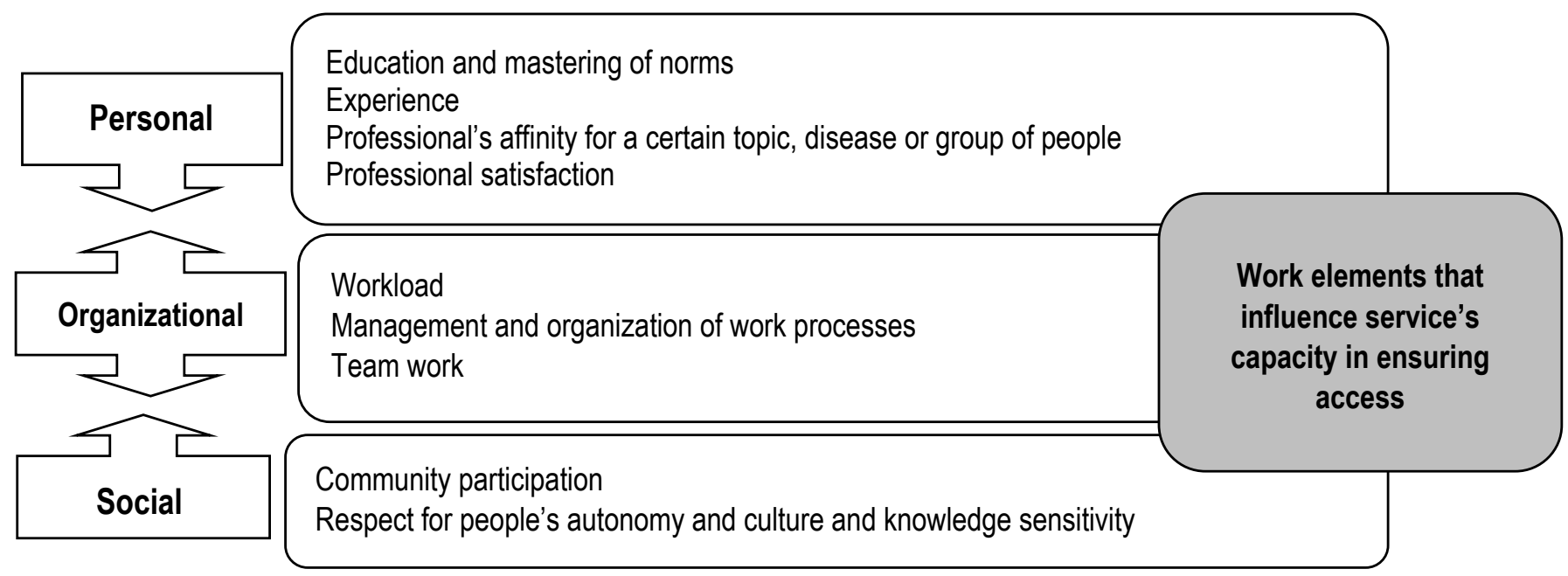

Figure 1. Elements of work that influence the ability of services in securing access

I think there have been other charges and we are linked to the PMAQ, which has many requirements that take a lot of time. These events would further strain the team. There are some manuals that we have to fulfill and we have to fulfill requirements as groups that we did not have before, [...] then it's another day taken from the care.

Training, whether in more permanent processes or in one-off courses, or at the beginning of the work in health teams (eg introductory), is a strategy for better appropriation of the great number of regulations that guide practices and for qualification of care as well as preparation in the technical courses and in the undergraduate in order to work in the FHS.

We have had several PMAQ meetings to discuss handbooks, to answer questionnaires, so we end up not knowing the handbooks themselves, but always working close to what they advocate. (ACSCO7).

For me, technical training equals a driver's license: you learn the basics of basic, the rest you will learn in practice ... the technical course does not give you any preparation. It prepares you to cover only a wellcovered gauze. (TECO2).

The results show that experience is fundamental for the accomplishment of actions in order to increase access, and this is recognized as part of the continuous process of retraining and preparation for real work.

I had 80 hours of course that gave me a basic idea, I learned in everyday life, each person, each family is different, there's no introductory course that gives you this experience, prepares you for all the situations you can meet. (ACSCO7).
Not being able to perform certain tasks and/or feeling under-supported makes the professionals reduce the range of actions they offer in the units and, consequently, access and resolubility.

I've had cases that I started and couldn't do it. Then I picked up the patient and put it in my car and said, «Are you not going to help me?» There is a lot of responsibility and you give up doing some things. (DCO1).

The identification of the professional with a particular activity, specialty or group of the population also contributes to a «selective» expansion of access. Some actions are carried out depending on the professional who is at the moment and ends up losing the regularity due to the turnover of the professionals.

The part that I like most is the Growth Development Program (CD Portuguese acronym), with children from 0 to 2 years, it's where I am spending every month in the house of these children, ... then we just hit the key promoting the health, in the part that you are most interested in, in the part that you feel most at ease. (ACSCO6).

During the time that I am here I had some (groups). Of the hypertensive patients, when the doctor was still there, she met them once a month. She made a group. Everyone was together, hypertensive, diabetic; then after the doctor left, another doctor came in, and then there were no groups. (TECO3).

An element closely related to the dimension of work organization (described below) is satisfactiondissatisfaction, interfering in the motivation, bond and commitment to the collaborative work. Thus, the lower 
supply of health actions is also influenced by the dissatisfaction of the professionals after a time of performance in the FHS:

Incentives. Both mine and collective. For there comes a time when we are not going after things because of a lack of willingness, not to get angry. So all that spirit of the course is lost when facing things that are going on throughout the career (ASCCO1).

The Organizational dimension for care and access: from the workload to the work management

The elements that refer to the organization of the work itself, or the way it may affect overload and dissatisfaction, for presentation purposes only can be separated from personal elements. In this dimension, the roles and contributions of different professionals and the potential of teamwork are recognized, as well as the importance of basic strategies and mechanisms for the organization of the demand and supply of actions so that the objectives of the care are achieved

Closely related to the previous dimension is the way in which work overload due to high demand, productivity requirement, turnover and absenteeism of the professional staff influences the supply of services, impacting care. The presence of violence in the communities where some health units are located, also interferes with the way health professionals organize their work.

There was a time when all made the visits, but recently that wasn't the case because of demands, there are many numbers to deliver and they cannot reconcile the two. (ACSCO1).

The case of violence interferes: even the day-care centers were not keeping the students two weeks ago, so I think this item is quite aggravating. Because if we schedule a group meeting and there is something out there they will not come. (TSBS1).

The search for offering access to all who need care ends up generating tiredness and dissatisfaction among health professionals. One report describes that the permanence inside the office is a way of not facing the problems presented by the community.

My work day is very busy as you see. It is very tiring. There are days when we do not have time to pee (TES2).

they even suffer more than I do because I spend most of the time locked in here taking care of curative medicine and they do go out into the field to deal with the problems that appear (MS2).
Decisions of managers on how to organize the work of teams is sometimes inattentive to the reality of health teams, discouraging professionals and reducing access.

The way home visits were defined drew attention. No criteria were used, but an active search demand of pregnant women in the area, like a «task force». It is a fact that the team emphasizes the accomplished work of family planning and not having pregnant women without prenatal care. However, they do not consider taking this to the manager and discuss/ justify the (planning from) the number of pregnant women in the area. (NO3).

The hours of operation and the excessive number of persons assigned interfere in the access both by the number of people and by the inability of the professionals to perform all of their duties. In addition, the high demand for medical care makes these professionals spend much of their time in the office.

Sometimes the family is not even registered [...] people who work and are (at residence) only at night, so we do not have the opportunity to register, but we know, so and so lives there (ACSCO5).

But the doctor only usually goes when it is extremely necessary. Because if we take the doctor from here for something that we ourselves can solve, I believe the community loses (ACSCO3).

Despite the high demand, there are empty units at certain times that show the «phantom demand».

And as I was doing more or less the same thing in the preventive, because I prearranged, there was a queue and at the same time people were missing their appointments. Then there was a pent-up demand and at the same time scarce demand. (ENFS1).

The presence of a physician and the provision of services such as vaccination contributed to an increase in demand, although some times were more crowded. The possibility of being seen every day of the week improved the flow of care and access.

In the waiting room, a teenage user arrives with her mother for vaccination. At UBS this procedure is offered every day. She sits down and is admired by the fact that she does not have to wait and is soon taken care of. (NO5).

Here, it is now free demand. People no longer need to come at dawn, they can come in the opening 
hours, they are all seen, regardless of what they have or do not, if not, they are scheduled. (TES2).

The form of scheduling is one of the elements described as capable of contributing to the existence of shifts without users in the units, as well as seasonality in the search for services. All teams work with priority attention to priority groups (pregnant women, the elderly, children, users with hypertension and diabetes). There is difficulty of the team in organizing the service considering both the spontaneous demand and the pre-programmed. The response to spontaneous demand appears to be poorly structured, hindering the access of those in acute situations or who are not part of the priority groups.

I see space outside the triage room, which is spontaneous demand and everyone who arrives has to be seen. This substracted some of the group space. (TES1).

We have to come here at the Unit either at 8 am or $1 \mathrm{pm}$ to get a slot. If some person is not missing, they will be left unattended even if they are in pain. (ACSCO6).

Strategies are used to meet spontaneous demand, such as a day of the week for appointments, waiting lists, scheduling ACS, and getting people into vacant slots. Emergencies generally have free access to care, although the teams reserve 2 or 3 vacancies/day for such cases:

But a matter of urgency is not on our agenda. If they arrive, regardless of our patients all, they will be seen. (TSBCO1).

In general, there are 8 scheduled demand consultations and 2 (urgency) appointments per period for each dentist. (NO6).

Even when the marking carried out with the ACS was justified, during the visit, as a strategy of accountability, no result of attendance was observed.

Most of the people who were scheduled to visit were out working. The ACS and the dentist left messages for people to go to the unit to make the appointment. It was possible to perceive the fragility of the dialing strategy used by the team, which resulted in a large waiting list and an empty agenda. (NO10).

The classification of risk does not appear in the routine of some teams and the cases are screened in an unsystematic way. Pain is pointed out as one of the main symptoms for screening users:

Then they ask who is in pain, the person who wants to do the treatment but is not in pain ends up getting left behind because we have to give priority to who is in pain at that moment. (ECO1).

In certain cases, access is given to a first appointment, placing the responsibility for the conclusion of the treatment exclusively on the users.

The person ends up being responsible for their treatment, because when they scheduled the return to consult, people were missing... so if I go four days in a row and get an appointment, awesome! you have finished your treatment. The responsibility is yours.. (ASBS2).

A practitioner points out, that even though they do not agree with the format for scheduling, they follow it because it is an old practice in the unit and standardized.

They are always the same ones that demand. Now, for those who do not come here, it is harder for you to bring them in. (I organize my work) seeing how it was, and then studying. When I got here I already had more or less this schedule. This day is a pregnant woman's care, so I'm going to take care of the pregnant woman... And we have the Ministry of Health's handbook. And that's the standard. (CDCO1).

In one of the units, the first service to the users is carried out by the unit's supervisor and, in another, by the ACS, which has influenced the access, as it distorts the worker's function and reduces the time for carrying out their own activities.

We spent a lot of time inside the unit, we took care of the most important cases of the micro area because we were without the administrative, so the health agent took over the reception. (ACSS1).

The reception/embracement also emerges as a strategy to increase access and users' satisfaction.

About the new model of reception/embracement, she responds that she is better because she did not have any troublemaking, none of them were lifethreatened. With the old system, whenever I finished I was always threatened and sometimes the police needed to be called. (NO13).

it's arduous because there are many people, but it has its advantages in that every patient looking for 
urgent care is seen. No one can go home without medical attention. This is the first one. The second, the whole team works, all together, with greater unity. (MS1).

The importance of the reception/embracement staff in the access and flow of the user within the UBS is highlighted. A professional and some users complain about the «reception» strategy established by the team, because it happens at a predetermined time and/or because it cannot be performed by the reference team.

In 2 hours the staff have to «look at» 20 people, and many are not from their area of expertise. And «look at» is not community health, she says with the expression of denial... some users listen to my quick conversation with her and come closer to say that they also do not like it because they wanted their specialist or nurses. (NO13).

The home visit is also described as an important tool to increase access.

Going to people's house who can not go to the unit, see how is their health, I always prioritize the home visit to these people because they need attention. (ASCS1).

Teamwork, as a promoter of exchange among the professions, contributes to an increase in access and aims at the production of care.

We exchange a lot too, talk about patients, [...] and then we exchange and say «look at this patient I think they have the same problem, maybe you talk to him». And if I have a patient that I know and I know that will be treated by her too, I may talk to them (ES1).

Nursing care has contributed to increase access and reduce the demand for medical consultation. The inclusion of other professional categories, through the NASF, has made possible access to other forms of care.

I do a lot of reception, guidance, some patients come to me to talk, most of the time I do not stay at the office seeing a patient, maybe that should be what's right, I do not know, and a lot of things go through me before going to the doctor, because sometimes the patient wants to renew a contraceptive prescription or some question that does not need to be referred to the doctor (ECO2).

There are people who started taking medicine and started to do physical activity and nowadays they do not take any more medicine. They began to have lower blood pressure. I wanted to find out why and it was because they were already exercising for a long time, so they (NASF) help a lot. (MS2).

The presence of the Oral Health Team in the Family Health Strategy is important, as well as the ACS, which contribute to broaden access and reduce the demand that arrives at the Unit.

Having a person who can give information to them and sometimes they do not need to come here to the unit for simple information they may be picking up with a community agent (ACSS2).

However, the inclusion of TSBs in the teams appears to be underutilized, since they have developed Oral Health Auxiliary (ASB) activities due to lack of equipment.

\section{The social dimension for care and access: participation and autonomy as values}

This dimension indicates a concern with qualified listening (knowing the needs) and resolubility, for which participation is more a strategy for the objectives of the work and less as a practice of citizenship and social control. By recognizing respect for the autonomy and culture of users as fundamental values of care practices, the incorporation of important elements for the quality of care shows.

The teams report little participation of users in the collective activities developed:

It was always very difficult to work with the population, so we organized groups: hypertension, diabetes. We would invite someone else to give lectures And no one would come. (DCO1).

The professionals' speeches indicate that community non-participation is due to the search for actions that result in responses to their health needs and affirm that they would like to learn strategies to work with the community.

The community here is not very participative. They want that resolute attention (ECO1).

Some strategies are used for greater participation of the community, such as associating collective activity with medical consultation, connecting to users the day before the activity, divulging in social networks, the use of play and activities in the community and not in UBS.

We have to figure out what moves people. What is their motivation to participate? In the group of 
pregnant women, for example, we try to coincide with the consultation, which is why membership is greater [...] we have created a facebook for the unit and our administrative assistant updates it with news (ES1).

The promotion happened in Alto Rancho dos Pescadores because they no longer come here for a consultation, not to mention a lecture, so we'll go there. (ACSS3).

Respect for users' autonomy and way of living, listening and bonding are important points for increasing access.

We had a doctor who went to do a home visit and said: let's open the window, ventilate the house, clean the house, this helps with health. The next day the patient said that she did not want this doctor in her residence again (laughs). [...] you have to be careful when you talk to the patient (ACSCO4).

And I think that when you have a bond with the patient, not leaving aside the professional side, you can really achieve what they need (TES1).

\section{DISCUSSION}

The results show that, although the time spent in $\mathrm{PHC}$ is more than six years, most workers refer they have never read the norms that guide their performance. The work in the FHS is regulated by a set of guidelines from the Ministry of Health, municipal and state governments. The number of programs that make up the health teams is is very large due to the complexity of the work and the fragmentation in the ways of looking at the health-disease-care process. In addition, some of the federal programs are linked to financial incentives and the achievement of goals. Both situations contribute to an increase in the (especially administrative) tasks of workers and are described as an element that interferes with access to care. The role prescribed for family health teams is broad in scope in that it requires longitudinal care, multi-purpose knowledge and capacity to act inter-sectorally ${ }^{10}$.

The workers affirm the importance of established knowledge (scientific, academic, related to professional practice). They also state that what is learned in training courses is not enough to respond to the demands of practice, highlighting the importance of the knowledge invested, produced at the time of the acts and that, for the most part, is not verbalized or written ${ }^{11}$. «To understand every working situation, these two forms of knowledge are indispensable. They constitute the two sides of all work activity, its dialectical unity ${ }^{12}$ (p.100).

It is necessary to create spaces in health units so that workers can reflect and learn from their practice, intentionally transforming na experienced situation into a learning object, leading the teams to know how to act and appropriate this knowledge ${ }^{11}$. The results also reflect the uncritical implementation of organizational regulations, associated with a low prioritization of permanent education actions in some units by workers and managers.

Management, when carried out vertically and distant from the local reality, is pointed out by interfering in the practices of the teams. In the management practices it is possible to normalize the work to a certain extent, since the normalization has limits and the rigidity is cause of suffering ${ }^{12}$. For work to flow with quality it is necessary to know what each worker wants, should and can do in each particular situation, not having a single model to be followed ${ }^{12}$.

In the testimonies, the workers seem to demand greater autonomy to carry out their actions according to the possibilities and needs of the environment, to be at the same time actors (performing what is requested by the environment) and authors (if put at the center of the decision) of health acts ${ }^{11}$. This need for autonomy is also perceived in the way some health services organize agenda and work processes.

Many units follow the recommendation by the Ministry of Health, "care based on knowledge and technologies aimed at the intervention of specific population groups that are appearing in the daily practice of the $\mathrm{FHS}^{\prime \prime 13}$ (p.447). The organization through program groups created in the imaginary of many workers and, with reflections in daily practice, the idea that PHC should be focused on promotion and prevention, and ruled that it would be up to the Health Unit to meet the spontaneous demand ${ }^{14}$. There is a contradiction present in health acts, and in the discourse of practitioners and managers, showing the prioritization of programmatic actions. However, they carry out most of the time care to specific symptoms and spontaneous demand ${ }^{15}$. It is necessary to analyze carefully the form of scheduling of consultations, which prioritizes risk groups, whether from collective activities or by micro area and/or health condition, as well as restricted time for screening, as it can help in the programming of the offer by the units, but it can also cause access restriction and user frustration ${ }^{16}$. 
The reception/embracement strategy is used as it is capable of organizing the agenda and the work of the teams. However, when developed only in a bureaucratic way, as an initial screening, differently from was conceived for this device, it reduces access ${ }^{17}$, producing a «barrier» of access of the users to the worker to whom they are «bound». Poor capacity to carry out a quality risk classification can also impair access with equity.

Risk classification is an important tool identified by the family groups to optimize priority access ${ }^{18}$. However, as evidenced, the service is limited to a sign of severity and excludes from attendance children with other signs that would also require immediate care.

Reception/embracement, educational actions and permanent education, bonding and accountability are pointed out as the main advances after 10 years of insertion of oral health teams in the EFS. The expansion and qualification of care, the comprehensiveness and the integrated work of the team still appear as challenges ${ }^{19}$.

In this research it was demonstrated that professional teams contribute to broadening access, when they practice practices that seek professional collaboration. The collaboration provides for the sharing of knowledge, experiences and skills in order to qualify the care offered, considering the complexity of doing in health ${ }^{20}$.

Within the FHS, the ACS is highlighted by its proximity and ability to facilitate communication between the community and the service, for example, in cases where it reduces the users' visits to the units. However, the deviation of the agents' functions to do activities such as reception in the unit reduces access in that it reduces the time for home visits ${ }^{6}$, as verified in the present research.

Lack of attention and listening to users' needs appears in this study as one more element that reduces the participation in the activities proposed by the teams, such as low adherence to educational activities. On the subject of health education, it is pointed out that «although the conceptions of Health Education based on a dialogic and emancipatory model are present as a goal in the studies on educational practices ... in the daily practice professionals still develop their actions, mostly based on the traditional model" (p.323) $)^{21}$ and that training is needed that promotes a paradigm shift and, consequently, of health education practices.

The traditional model of health education focuses on curing the disease, prevention linked to the change of individual attitudes and behaviors, the transmission of vertical information and prescription of behaviors, seeing the user as a person without information and the professional as the holder of the knowledge, capable by simply transmitting information, to modify people's lives ${ }^{22}$. Thus, it acts by blaming the victim (user) and transferring responsibility for the care and healthdisease process to the population ${ }^{23}$. In the production of care, it is necessary to consider the knowledge of all involved, in an ethical posture of listening, respect, inclusion, doubt and search, considering the unforeseen and the unforseeable that are present at work $^{12}$.

Finally, the study corroborated that there are elements of work in the FHS that contribute to increase the workload, dissatisfaction and sickness of workers, such as excess demand; violence, lack of investment in quantity and professional qualification; as well as elements that reduce loads and cause greater satisfaction, such as teamwork and the presence of ACS $^{24}$. In the relationship between workloads and universality of access, the elements that contribute to an increase in workloads hamper access to health services ${ }^{10}$.

\section{CONCLUSION}

The analysis of the findings of the study made it possible to highlight elements present in the way health care workers produce care and their relation with access to health services. Those elements relate to individual issues and the organization of the service and the relationship and participation of the community in the actions of the unit. They are articulated in three dimensions, but they are interrelated and should be considered in the training of new health professionals/ workers as well as in the formulation of federal and local policies, strategies and programs.

\section{ACKNOWLEDGMENTS}

To the Brazilian Federal Agency for Support and Evaluation of Graduate Education of Brazil - CAPES for the granting of the sandwich doctorate scholarship Process - 88881.132441 / 2016-01 to Erica Lima Costa de Menezes. To the Federal District Research Support Foundation - FAP/DF for the granting of the postdoctoral scholarship - Protocol 11503.60.30322.04072016, to Magda Duarte dos Anjos Scherer. 


\section{REFERENCES}

1. Assis MMA, Villa TCS, Nascimento MAA do. Acesso aos serviços de saúde: uma possibilidade a ser construída na prática. Ciênc. saúde coletiva. 2003;8(3):815-23.

2. Feuerwerker LCM. Micropolítica e saúde: produção do cuidado, gestão e formação. Porto Alegre: Rede UNIDA; 2014.

3. Schwartz Y. Intervenção, experiência e produção de saberes. Revista Serviço Social \& Saúde. 2011; X(12):19-43.

4. Agreli HF, Peduzzi M, Silva MC. Patient centred care in interprofessional collaborative practice. Interface. 2016;20(59):905-16.

5. Oliveira LS, Almeida LGN, Oliveira MAS, Gil GB, Cunha $A B O$, Medina $M G$ et al. Acessibilidade a atenção básica em um distrito sanitário de Salvador. Ciênc. saúde coletiva. 2012;17(11):3047-56.

6. Lima SAV, Silva MRF, Carvalho EMF, Cesse EAP, Brito ESV, Braga JPR et al. Elementos que influenciam $O$ acesso à atenção primária na perspectiva dos profissionais e dos usuários de uma rede de serviços de saúde do Recife -PE, Brasil. Physis Revista de Saúde Coletiva. 2015;25(2):635-56.

7. Chagas MIO, Farias CMT, Teófilo FKS, Cavalcante ASP. Acesso dos usuários aos serviços de saúde na Estratégia Saúde da Família: percepção dos enfermeiros. Rev. APS. 2014;17(3):280-90.

8. Schwartz Y, Durrive L (orgs). Trabalho e ergologia: conversas sobre a atividade humana. Niterói: EdUFF, 2007.

9. Franca MB, Muniz HP. A gestão coletiva dos serviços de saúde pública: uma perspectiva ergológica. Trab. educ. saúde. 2011;9(1):201-21.

10. Pires DEP, Machado RR, Soratto J, Scherer MA, Gonçalves ARS, Trindade LL et al. Nursing workloads in family health: implications for universal access. Rev. Latino-Am. Enfermagem [periódico na Internet]. 2016 [Acess 04 de mai 2017]; 24:e2682 Available in https://www.revistas.usp.br/rlae/article/ view/113366/111328.

11. Durrive L. A atividade humana, simultaneamente intelectual e vital: esclarecimentos complementares de Pierre Pastré e Yves Schwartz. Trab. Educ. Saúde. 2011;9(1):47-67.

12. Trinquet $P$. Trabalho e educação: o método ergológico. Revista HISTEDBR On-line. [periódico na Internet]. 2010 [Acesso em 06 de mai 2017]; Número especial: 93-113. Disponível em: https:// periodicos.sbu.unicamp.br/ojs/index.php/histedbr/ article/view/8639753/7318.

13. Lima WCMB, Assis MMA. Acesso restrito e focalizado ao Programa Saúde da Família em Alagoinhas, Bahia, Brasil: demanda organizada para grupos populacionais específicos $x$ demanda espontânea. Rev Baiana Saude Publica. 2010;34(3):439-49.

14. Tesser CD, Norman AH. Repensando o acesso ao cuidado na Estratégia Saúde da Família. Saúde e Sociedade. 2014;23(3):869-83.

15. Coimbra VCC, Oliveira MM, Kantorski LP, Heck RM, Jardim VMR, Ceolin T. Avaliação da estrutura - processo de acesso de usuários a uma Unidade de Saúde da Família. R. pesq.: cuid. Fundam. [periódico na Internet]. 2010 [Acesso em 01 de mar 2017]; 2(3):1095-107. Disponível em: http:// www.seer.unirio.br/index.php/cuidadofundamental/ article/view/591/pdf_47.

16. Cunha ABO, Vieira-Da-Silva LM. Acessibilidade aos serviços de saúde em um município do Estado da Bahia, Brasil, em gestão plena do sistema. Cad. Saúde Pública. 2010;26(4):725-37.

17. Taddeo PS, Gomes KWL, Caprara A, Gomes AMA, Oliveira GC, Moreira TMM. Acesso, prática educativa e empoderamento de pacientes com doenças crônicas. Ciênc. saúde coletiva. 2012;17(11):2923-30.

18. Silva RMM, Vieira CS. Acesso ao cuidado à saúde da criança em serviços de atenção primária. Rev Bras Enferm. 2014;67(5):794-802.

19. Scherer $\mathrm{Cl}$, Scherer MDA. Advances and challenges in oral health after a decade of the Smiling Brazil Program. Revista de Saúde Pública [periódico na Internet].2015 [Acesso em 01 de mar 2017]; 49:98. Disponível em: https://www.scielosp.org/pdf/rsp/ v49/pt_0034-8910-rsp-S0034-89102015049005961. pdf

20. Furtado JP. Reference teams: an institutional arrangement for leveraging collaboration between disciplines and professions. Interface - Comunic. Saúde Educ. 2007;11(22):239-55.

21. Rodrigues D, Santos VE. A educação em saúde na estratégia saúde da família. J Health Sci Inst. 2010;28(4):321- 4.

22. Alves VS. Um modelo de educação em saúde para o Programa Saúde da Família: pela integralidade da atenção e reorientação do modelo assistencial. Interface (Botucatu) [periódico na internet]. 2005 [Acesso em 03 de fev 2017]; 9(16):39-52. 
Disponível em: http://www.scielo.br/pdf/icse/v9n16/ v9n16a04.pdf.

23. Berlinger G. Ética da Saúde. São Paulo: HUCITEC, 1996.

24. Trindade LL, Pires DEP, Amestov SC, Forte ECN, Machado FL, Bordignon M. Working in The Family Health Strategy: implications in professionals workloads. Cogitare Enferm. 2014;19(3):405-92. 